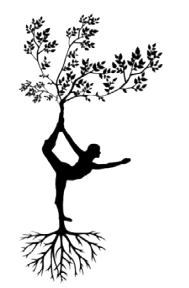

$21^{\text {sT }}$ CENTURY PEDAGOGY

Transformations of the Education Systems in Europe and in Asia

at the turn of $20^{\text {th }}$ and $21^{\text {st }}$ century

Vol. I, 47-60

DOI: $10.2478 / \operatorname{ped} 21-2018-0008$

Yong Mei

Hubei University, People's Republic of China

\title{
Transformation and Trend of Doctoral Education in China and Poland (1980s-2010s). A Comparative Study
}

Key words: doctoral education; comparative study; transformation and trends

\section{Abstract}

The past 30-strong years has seen remarkable achievements that both Poland and China have made in Doctoral Education along different paths though. Drawing on policy research and extensive data, this paper sets out to examine the transformations of doctor education across the two countries within these intervening years. It is found that the changes in Poland were mainly influenced by the political transitions, its integration with European education system, and particularly the Bologna Process while China's educational reform was amenable to the national economic policy and the government behavior. As regards the prospect of doctoral education, the two countries have both common grounds and differences. Poland and China will have more diversified structure in doctoral education, pay closer attention to STEM discipline's developments as well as external and intermediary assessment in quality control. Also, the managements of doctoral programs in two countries will be characterized by further decentralization of government and internationalization of education. In the next few years, however, the scale of China's doctoral education will remain at the current level or even expand modestly, whereas that of Poland's doctoral education is likely to shrink due to the population decline.

\section{Introduction}

Competition among higher education has been growing increasingly tense, particularly in the sector of doctoral education. Understandably, this field has become "a matter of increasing interest and concern" in many parts of the world (Lee \& Green, 1995, p. 2), including China and Poland.

Distant and different as these two countries might seem, they have one crucial commonality in their higher education system: both had been heavily impacted by the former Soviet Union. After splitting up with their former model, the two countries have seen their higher education on different tracks but both have achieved progress by leaps and bounds. To date, Poland is the $4^{\text {th }}$ largest higher education system (after UK, Germany, and France) in the European Union according to the Ministry of Science and Higher Education in Poland, while China ranks the second largest globally. In terms of doctoral education, Poland underwent 
a major transformation after the country's political transition began in 1989, while China initiated such programmes only in early 1980s under Deng Xiaoping's leadership then. How could their PhD education grow so robustly within a relatively short period? It merits due attention to explore what contributes to their commendable progress. Specifically, two key aspects are to be discussed in depth. Firstly, as two emerging powers of higher education, what are the major transformations in their doctoral education over the past several decades? It helps to master the main features of current doctoral education in Poland and China. Secondly, what are their prospects ahead in the field? Especially when they spare no efforts to guarantee the "gold standard" of their doctoral education in the context of massification of higher education. Against the backdrop, it is conducive for them to benefit from well-established practice from each other.

\section{Literature review}

Comparisons of higher education between China and Poland have not been abundant but are on the increase. In Chinese literature, initial research about Poland was informative and to introduce polish higher education, and become gradually more academic. There are analysis about Polish engineering education reform (Chen,1998) , its agricultural education (Huang, 2001) , its mode of higher education and references to Chinese colleges and universities (Huang, 2002), the non-public higher education institutions (Sun \& Xia, 2003), the EFL teaching at Polish higher education institutions and its implication for China (Che, 2005), the accreditation system of quality control in polish higher education (Pang, 2006), review and development of entrepreneurship education (Huang \& Ke, 2011; Wang, 2011), as well as a summary of its new trends and implication of transformational development after 1989 (Yang, 2015). Among the literature, Fan's work (2001) was one of the earliest efforts in comparing the development and reforms of higher education systems in both countries and their respective pros and cons. In governing higher education institutions, Poland was more open and effective while Chinese higher education institutions had more contact with market. Wang (2010) has directly discussed the current state and existing problems in polish doctoral education, introducing the structure and programmes of its doctoral study, and pointing out that quality control and level of internationalization of doctoral education are two major challenges.
Research on Chinese doctoral education has gained increasing interest due to its huge size and fast growth, covering facets such as the its history and review, recruiting strategies, quality and its control (Chen, et al., 2010 ). Probably out of geographical and ideological causes, there is little comparison of higher education between two countries written in English. An indirect and interesting comparison could be established by two separate studies: Koscielniak (2014) and Holm, Sammalisto \& Vuorisalo (2015) addressing the same issue, i.e., education for sustainable development.

In term of comparison of doctoral education, Wildy, Peden \& Chan (2015) compare the development of professional doctorate in China, Iceland and Australia. They find that the emergence of professional doctorates worldwide is having a significant impact on the status and structure of traditional research-based $\mathrm{PhDs}$ and on the roles of academics and students in the so-called knowledge economy. Regarding China and Poland, the most immediate endeavour is the informative and inspiring book The Doctorate Worldwide by Stuart Powell $\&$ Howard Green (2007). Their internationally coordinated research has critically analyzed the provision of doctoral education worldwide and discusses core issues for educators, administrators and policy-makers when planning and delivering doctoral education programmes. The book has offered a sound and solid analytical framework with a couple of index for comparison between seventeen countries, including questions such as place of doctoral study, funding issues, institution types, forms of doctoral study, students and their programs of study, supervision, examination, and so on. Despite being relatively marginal, doctoral education in both Poland and China have been discussed and delved with hard data. Presumably, the research has been initial endeavor to compare and summarise key aspects of doctoral education of these two countries in a coherent way. However, due to space limit, Stuart Powell \& Howard Green's investigation and account for each country have been limited to 4,000 words, including China and Poland. Besides, substantial and substantive changes have occurred to graduate education in the past decade in the countries. Against the backdrop, it is significant to revisit the issue.

\section{A panorama of higher education systems in China and Poland}

Poland's traditions of academic education date back to 1364 when King Casimir the Great established the 
Cracow Academy, known today as the Jagiellonian University. Today, the Polish higher education system is developing dynamically and has ranked the fourth place in Europe (Ministry of Science and Higher Education, 2012). The total student population at over 430 higher education institutions (shortened as HEIs here-after) numbers almost 2 million.

Poland conforms to the guidelines from the Bologna Process in European higher education where the degree system based on the three-cycle structure has been successfully implemented. In many literatures, the history of Polish higher education has a clear demarcation line around 1989. After 1989, the expansion and diversification of higher education have quickened, with numerous new sorts of colleges and universities established in the nation. In 2005, there were 445 HEIs, and increased to 460 in 2010, but gradually declined to 434 in 2015. In terms of enrollment, according to 2014 GUS data, the enrollment rate of Polish higher education is $26.8 \%$. However, after years of a dramatic increase in demand, Polish higher education enrollment will decline sharply by 2025. GUS data in 2011 indicated that in the past six years the total enrollment has decreased by 9.7 percent (Joanna Musial, 2014). It is further supported by the 2015 Demographic Yearbook, where the number of students in total at HEIs was $1,953,800$, and then shrank to $1,841,300$ in 2010 and declined to $1,469,400$ in 2015.

The Ministry of Science and Higher Education is the governmental organization in charge of scientific and higher educational development. HEIs in Poland are divided into state (public) and private (non-public) institutions. There are two main categories of higher education institutions: university-type and non-university institutions. In the university-type HEIs, at least one unit is authorised to confer the academic degree of Doctor $(P h D)$, i.e. offers at least one doctoral programme.

China has similar categorization in its HIEs but with different naming. There are public, non-public colleges and universities (also called Minban or independent), as well as academic institutions (such as Academy of Science of China and Academy of Social Sciences of China).

The Regulations on Academic Degrees of the People's Republic of China, as one major act on its degree systems of higher education, was adopted at the $13^{\text {th }}$ Meeting of the Standing Committee of the Fifth National People's Congress on February 12, 1980 and later amended at the $11^{\text {th }}$ Session of the Standing Committee of the Tenth National People's Congress on August
28, 2004. The Act demonstrates that China also adopts the three-cycle degree system (Bachelor-Mater-Doctor), where only authorized HEIs are eligible to confer bachelor degree and authorized HEIs and academic institutions can confer master and doctor degrees.

The Ministry of Education (MoE) of China, a government ministry responsible for all aspects of state education at all levels ranging from primary education to higher education including doctoral provision. According to the MOE's annual report in 2014, there are 2,845 HEIS, including public and 722 non-public institutions, adding another 36 after 2013. Besides, there are over 25 million students at all Chinese HEIs with an increase $3.23 \%$ year-on-year, creating one of the largest higher education systems with the gross enrolment rate of higher $37.5 \%$.

Table 1. Higher Education in China and Poland in the 2014/2015 Academic Year

\begin{tabular}{|c|c|c|c|c|c|}
\hline & 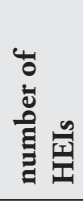 & 总 & 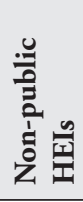 & 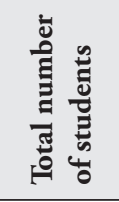 & 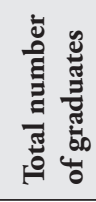 \\
\hline China & 2,845 & $\begin{array}{c}1,53 \\
\text { million }\end{array}$ & 722 & $\begin{array}{l}25,477 \\
\text { million }\end{array}$ & $\begin{array}{l}6.59 \\
\text { million }\end{array}$ \\
\hline Poland & 434 & 96,500 & 280 & $\begin{array}{c}\text { Nearly } 2 \\
\text { million }\end{array}$ & $\begin{array}{l}0.425 \\
\text { million }\end{array}$ \\
\hline
\end{tabular}

Source: Data about China are from the website of MoE of P.R.C. Data about Poland are from 2015 GUS, Concise Statistical Yearbook of Poland.

\section{Current state of Doctoral education in China and Poland}

Due to historical influences, both Poland and China have complicated higher education systems, mainly containing HEIs and other academic institutions. Although the latter are also involved in doctoral education, they are secondary in scope and proportion in comparison with the former. For instance, according to Central Statistical Office, in 2006 Polish HEIS accounted for $92.6 \%$ of doctoral students (Krasniewski, 2008). Therefore, this paper mainly concentrates on the doctoral education carried out at HEIs in both countries. 
Table 2. Doctoral Education in Poland and China in the 2014/2015 Academic Year

\begin{tabular}{|c|c|c|c|c|}
\hline \multirow[t]{2}{*}{ Items } & \multicolumn{2}{|l|}{ Poland } & \multicolumn{2}{|l|}{ China } \\
\hline & Number & Details & Number & Details \\
\hline $\begin{array}{l}\text { Total number of doctoral } \\
\text { students studying }\end{array}$ & 40,575 & $54.3 \%$ are females & 312,676 & $36.9 \%$ are females \\
\hline PhD graduates & 5,712 & 2,976 are females & 53,653 & \\
\hline Entrants & No data & & 72,634 & \\
\hline $\begin{array}{l}\text { Number of institutions } \\
\text { offering doctoral } \\
\text { programmes }\end{array}$ & More than 100 & & 288 & \\
\hline $\begin{array}{l}\text { Number of different } \\
\text { doctoral awards } \\
\text { (e.g. including } \\
\text { professional doctorates) }\end{array}$ & 2 & $\begin{array}{l}\text { Regular PhD degree } \\
\text { and } \mathrm{PhD} \text { in the arts }\end{array}$ & 2 & $\begin{array}{l}\text { Regular PhD degree } \\
\text { and professional } \\
\text { doctorates }\end{array}$ \\
\hline $\begin{array}{l}\text { History of offering } \\
\text { doctorates in the country }\end{array}$ & $\begin{array}{l}\text { Over } 500 \\
\text { years }\end{array}$ & $\begin{array}{l}\text { Since the } 15^{\text {th }} \\
\text { century (Jagiellonian } \\
\text { University,Cracow) }\end{array}$ & Over 30 years & $\begin{array}{l}\text { The first cohort } \\
\text { of } 18 \text { students awarded } \\
\text { a PhD on } 27 \\
\text { May } 1983\end{array}$ \\
\hline $\begin{array}{l}\text { Proportion of fulltime to } \\
\text { part-time students }\end{array}$ & $5.69: 1$ & $\begin{array}{l}40575 \text { is the total } \\
\text { number at HEIs, } 6064 \\
\text { students are in part-time } \\
\text { programmes }\end{array}$ & $5.7: 1$ & $\begin{array}{l}305833 \text { is the total } \\
\text { number of PhD students } \\
\text { at HEIs; } 53651 \text { being in } \\
\text { contractual programs }\end{array}$ \\
\hline PhD supervisors & No data & $\begin{array}{l}\text { 7,753 are full professors } \\
\text { at HEIS (GUS, 2015) }\end{array}$ & 13,779 & $\begin{array}{l}2,074 \text { is female } \\
\text { supervisors }\end{array}$ \\
\hline $\begin{array}{l}\text { Average time to } \\
\text { completion (in years) }\end{array}$ & $\begin{array}{l}93.5 \% \text { of students } \\
\text { complete their studies } \\
\text { within } 2-4 \text { years }\end{array}$ & $\begin{array}{l}\text { The statistical data show } \\
\text { only the number of years } \\
\text { passing since the date } \\
\text { of the opening of the } \\
\text { doctorate procedure. } \\
\text { (Kwiek, 2006) }\end{array}$ & 3-4 years full-time & $\begin{array}{l}\text { No official data exist but } \\
\text { regulations of most HEIs } \\
\text { specify 3-4 years for } \\
\text { full-time students }\end{array}$ \\
\hline Success rates & No data & $\begin{array}{l}\text { No data available; but } \\
\text { probably the drop-out } \\
\text { rate is small with less } \\
\text { than } 10 \% \text { in public HEIs } \\
\text { (Kwiek, 2006) }\end{array}$ & No data & $\begin{array}{l}\text { No official data exist } \\
\text { but the real figures are } \\
\text { probably low due to } \\
\text { traditional Chinese } \\
\text { practice of "strict at } \\
\text { entry and relax at exit?" } \\
\text { (Zhuang, 2007) }\end{array}$ \\
\hline $\begin{array}{l}\text { Typical age range of } \\
\text { doctoral candidates }\end{array}$ & $24-30$ & $\begin{array}{l}\text { The vast majority } \\
\text { of doctoral students } \\
\text { begin doctoral studies } \\
\text { immediately after } \\
\text { graduation at (usually) } \\
\text { age } 24 \text { and studies last } \\
\text { (on average) } 4-5 \text { years }\end{array}$ & 30 years and below & $\begin{array}{l}40.4 \% \text { according to } 2008 \\
\text { data and likely to remain } \\
\text { so because most HEIs } \\
\text { tighten the rate for on- } \\
\text {-the-job students }\end{array}$ \\
\hline Graduate school & No data & & 56 & $\begin{array}{l}\text { All areresearch } \\
\text { universities of } 985 \text { Project }\end{array}$ \\
\hline
\end{tabular}

Source: Data about China are from the website of MoE of P.R.C.

Data about Poland are from 2015 GUS, Higher Education Institutions and their Finances in 2015.

The table has illustrated the general landscapes of doctoral education in two countries. They share similarities and also differences. For instance, both countries have three-cycle structure of degree system, high completion rate in doctoral studies and two types of doctoral programmes. Understandably, they also have major distinctions. Most typically, Poland has much longer his- tory in graduate education in China while the latter has more recent yet robust progress in the field.

For Poland, after implementing the three-cycle structure of degree system, the third-cycle studies is Doctoral degree programmes (normally 3 to 4 years) accessible for graduates of Master's degree programme, leading to a $\mathrm{PhD}$ degree, offered by the university type 
schools. The $\mathrm{PhD}$ degree is awarded to candidates who submit and successfully defend a doctoral dissertation before the thesis committee and pass the doctoral examination.

Two scientific degrees can be earned in Poland: the doctorate and the habilitation (the latter coming from the German academic tradition widely spread in Central Europe). In the Polish structure of higher education, the habilitation opens the way from being a junior faculty member to becoming a senior faculty member; however, full seniority of rank is only achieved with the award of the scientific title of professor. The habilitation, however, opens the way for an academic to become a university professor (a university function, without a scientific title). Background information on numbers, sex and distribution among disciplines of doctorates is given and discussed below. In the Polish context, it may also be useful to combine these data with the data concerning the habilitation. In Poland the doctoral education is primarily a gateway to academia that links to the habilitation, which in turn provides the license to practice as an academic (Stuart \& Howard, 2007, p. 232).

The list of institutions (in the case of HEIs, individual faculties) that are entitled to award $\mathrm{PhD}$ degrees in a particular area is determined by a state controlled body: the Central Commission for Academic Degrees and Titles. The decisions of this Commission are based on an evaluation of the research potential of institutions, mainly the number of full-time professors. Currently more than 100 HEIs include at least one unit entitled to award doctoral degrees (among them seven private HEIs); these HEIs are members of the Conference of Rectors of Academic Schools in Poland (CRASP). It must be emphasised, however, that, in principle, individual faculties (and not institutions) are primarily responsible for the development and implementation of doctoral programmes.

A candidate for the $\mathrm{PhD}$ degree should hold a master's degree (in theory it is possible to award the $\mathrm{PhD}$ degree to a person who does not satisfy this requirement, but in this case the procedure is extremely complex and, therefore, very rarely practiced). A graduate from a master's programme seeking a $\mathrm{PhD}$ degree is faced with the following two basic options. Partly similar to the case in Germany, the role of doctoral candidate has been largely a researcher, who doesn't have many courses to attend and are expected to carry out academic study.

For China, doctoral education has also been regarded as the highest form of its education system. Hence, China has highlighted the standard of doctoral education in its law. The Article 6 of Regulations on Academic Degrees in China stipulates that the doctor's degree shall be conferred on postgraduates in institutions of higher learning or scientific research institutes or persons with qualifications equivalent to postgraduates on graduation, who have passed examinations in the required courses for the doctor's degree and successfully defended their dissertations and have attained the following academic standards:

1) having a firm and comprehensive grasp of basic theories and profound and systematic specialized knowledge in the discipline concerned;

2) having the ability to undertake independent scientific research; and

3) having made creative achievements in science or in a special technology.

Abstract as those requirements might sound for $\mathrm{PhD}$ students in China, they are demanding for most students. Unlike their Polish counterparts, PhD students in China are largely regarded as students, so they will attend courses to train their research skills and capacity which normally last around one year.

As regards governance of doctoral education, $\mathrm{PhD}$ programmes are offered by selected regular HEIs and research institutes (RIs) subject to strict government approval procedures (Zhuang, 2007). Practically, graduate school has played a critical role in the administration of doctoral programmes. Since October 1984, China has approved of the first batch of graduate schools in 22 research universities, and hitherto 58 graduate schools (56 at HEIs) are established. The MoE's official website claims that the graduate schools have produced around $67 \%$ of $\mathrm{PhD}$ graduates for the nation.

\section{Transformations of doctoral education in China and Poland}

The evolution of Chinese doctoral education has been fundamentally driven by the national economy and keeping aligned with its economic landscapes while the transformations in Poland has been largely prompted by political transition and integration, coupled with demographic alternation.

\section{Stages of doctoral education in Poland}

Much research about evolution of Polish higher education presents an overall picture rather than on doctoral education. It has been already revealed that, like 
other sectors of its education system, Polish doctoral education has been acutely impacted by the adjustment during the Political transformation (Kwiek, 2013) and the transformation alongside with its alignment with Bologna Project (Krasniewski, 2008). Although not explicitly concerning doctoral education, in his analysis, Kwiek (2013) reveals that higher education in Poland has witnessed a process from system expansion to sys- tem contraction within the past 3 decades. The doctoral education is likely to undergo same transformation. Yang (2015) then proposes that there are three stages for polish high education. Based on Kwiek's insightful research and other scholars' analyses, the paper proposes that over the past three decades, Polish doctoral education has witnessed three major stages, detailed in the table 3 .

Table 3. Stages of Polish doctoral education from 1980s to 2010s

\begin{tabular}{|l|l|l|l|l|}
\hline Stage & Period & Feature & Causes & Description \\
\hline 1. & During 1980s & unified and Slow & $\begin{array}{l}\text { Tight and bureaucratic } \\
\text { control of the government } \\
\text { on higher education } \\
\text { (Musial, 2014) }\end{array}$ & $\begin{array}{l}\text { Polish higher education lacked autonomy and was not } \\
\text { inclined to encourage expansion; the number of students } \\
\text { was strictly controlled, including the number of doctoral } \\
\text { programmes. }\end{array}$ \\
\hline 2. & $\begin{array}{l}\text { From 1989 to } \\
2005\end{array}$ & $\begin{array}{l}\text { Expanding and } \\
\text { diversifying }\end{array}$ & $\begin{array}{l}\text { Mainly as the result } \\
\text { of political transition } \\
\text { in late 1980s }\end{array}$ & $\begin{array}{l}\text { During 1989-2005, Polish higher education have } \\
\text { undergone a process of deinstitutionazation and } \\
\text { privatization, with new and private HEIs cropping up. } \\
\text { Since 1990 the total number of doctoral students has } \\
\text { increased by a factor of 12: from less than 2,700 } \\
\text { in the academic year 1990-1991 to almost 33,000 } \\
\text { in the academic year 2005-2006. }\end{array}$ \\
\hline 3. & $\begin{array}{l}\text { From 2006 to } \\
\text { now }\end{array}$ & $\begin{array}{l}\text { Keeping steady } \\
\text { even shrinking } \\
\text { with declining } \\
\text { schooling } \\
\text { population; } \\
\text { From unstructured } \\
\text { model to } \\
\text { structured one; } \\
\text { From }\end{array}$ & $\begin{array}{l}\text { Decisive Integration } \\
\text { with EU: Alignment } \\
\text { with Bologna Process } \\
\text { and conforming with } \\
\text { EU'S requirements such } \\
\text { as the Bergen } \\
\text { Communique }\end{array}$ & $\begin{array}{l}\text { After 2005, the regulations in organizing doctoral studies } \\
\text { have shifted from The Act on Scientific Titles and Degrees } \\
\text { to The Act on Higher Education; The status of PhD } \\
\text { students shifting from scientific apprentice to multi-skilled } \\
\text { knowledge worker; Since 2006, Polish higher education } \\
\text { was downsizing due to declining population. In 2007 } \\
\text { there were 6,072 PhD graduates but shrank sharply } \\
\text { to 3,590 in 2012. }\end{array}$ \\
\hline
\end{tabular}

Source: from Education and Training, Graduates by field of education[DB/OL].

http://stats.oecd.org/ 2015-01-21.

\section{Stages of doctoral education in China}

The scenario in China looks rather distinct. The predominant drive is out of economic consideration but pushed by government, which was initiated in the national policy of "Reforming and Opening-up to Outside World" in late 1970s. As Yang (2012) points out, in line with China's massive leap in higher education, doctoral education has been strongly, and arguably strategically pushed by the Chinese government. Needless to say, other factors also contribute to the transformation in doctoral education, just as Ma's study (2007) analyzes, graduate education in China is closely related to the country's scientific policy and education reforms. In a sense, the evolution of doctoral education is typical of state-controlled as well as government-led reforms.

After a slow growth during 1980s and 1990s, doctoral education in China has witnessed a leap around 2000. Within four decades, its scale has become one of the largest globally. Regarding the stages of Chinese doctoral education, there have been different evaluations, from perspective of the expansion of doctoral education (Guo, 2009), or from the history of authorization of doctoral programmes (Lin, 2009; Song \& Mei, 2009). As state-controlled higher education system, the changes in the authorization of doctoral programmes are convincing indicators of evaluation in the field. 
Table 4. Stages of authorization of doctoral programmes in China

\begin{tabular}{|c|c|c|c|c|}
\hline Stages & Period & Feature & Causes & Descriptions \\
\hline $\begin{array}{l}1 . \\
\text { Initial } \\
\text { establishment: }\end{array}$ & $\begin{array}{l}\text { From } 1981 \text { to } \\
1989 \text { Covering } \\
\text { the } 1^{\text {st }}-3^{\text {rd }} \text { rounds } \\
\text { of authorizations }\end{array}$ & $\begin{array}{l}\text { Slow and tightly stated- } \\
\text {-controlled }\end{array}$ & $\begin{array}{l}\text { Lacking talents and motivated } \\
\text { by gradual marketization after } \\
\text { implementing the policy of } \\
\text { "Reforming and Opening-up to } \\
\text { Outside World" }\end{array}$ & $\begin{array}{l}\text { implement high standard } \\
\text { and strict requirement } \\
\text { of graduate education, } \\
\text { guarantee its quality, } \\
\text { fairness and scientific } \\
\text { development }\end{array}$ \\
\hline $\begin{array}{l}2 . \\
\text { Consolidation } \\
\text { \& adjustment: }\end{array}$ & $\begin{array}{l}\text { From } 1990 \text { to } \\
1999 \text {; Covering } \\
\text { the } 4^{\text {th }}-7^{\text {th }} \text { rounds } \\
\text { of authorizations }\end{array}$ & Quick expansion & $\begin{array}{l}\text { 1. The demand for high-level labour } \\
\text { force is acute while HEIs are far from } \\
\text { meeting the demand; } \\
\text { 2. The national policy to establish } \\
\text { world-class universities has been } \\
\text { implemented, Such as } 211 \text { Project } \\
\text { and } 985 \text { Project. }\end{array}$ & $\begin{array}{l}\text { Consolidate the foundation } \\
\text { of current graduate } \\
\text { education, increase a small } \\
\text { number of master and } \\
\text { doctoral programmes; } \\
\text { During } 1992-1998 \text {, the } \\
\text { annual rate of doctoral } \\
\text { students studying on } \\
\text { campus is } 20.6 \%\end{array}$ \\
\hline $\begin{array}{l}3 . \\
\text { Active \& rapid } \\
\text { development: }\end{array}$ & $\begin{array}{l}\text { From } 2000 \\
\text { to } 2005 ; \\
\text { Covering the } \\
8^{\text {th }}-9^{\text {th }} \text { rounds of } \\
\text { authorizations }\end{array}$ & $\begin{array}{l}\text { Accelerated } \\
\text { development }\end{array}$ & $\begin{array}{l}\text { Hit by the 1990s Asian Financial } \\
\text { Crisis, the government decided to } \\
\text { stimulate economy by expanding the } \\
\text { scale of higher education, including } \\
\text { doctoral education. }\end{array}$ & $\begin{array}{l}\text { Promote active } \\
\text { development, deepen } \\
\text { reforms, adhere to high } \\
\text { standard and fairness; } \\
\text { The number of PhD } \\
\text { students has skyrocketed } \\
\text { from } 218,000 \text { to over } 1 \\
\text { million in } 2006 \text {, with } \\
\text { annual rate of } 24.48 \% \\
\end{array}$ \\
\hline $\begin{array}{l}4 . \\
\text { Optimization } \\
\text { \& improvement: }\end{array}$ & $\begin{array}{l}\text { From } 2006 \text { to } \\
\text { today; Since the } \\
10^{\text {th }} \text { round of } \\
\text { authorization to } \\
\text { today }\end{array}$ & $\begin{array}{l}\text { Closely monitored and } \\
\text { quality-centred }\end{array}$ & $\begin{array}{l}\text { 1. The negative impact of Great Leap } \\
\text { in higher education during the } 1990 \text { s } \\
\text { has emerged, with sharp criticism on } \\
\text { lowering quality of higher education. } \\
\text { 2. As integral part of building } \\
\text { "World-class Universities", the } \\
\text { quality of doctoral education has } \\
\text { been stressed. }\end{array}$ & $\begin{array}{l}\text { Adhere to high standard, } \\
\text { optimize the structure, } \\
\text { improve the quality; The } \\
\text { scale of doctoral graduates } \\
\text { has increased by } 25.93 \% \text {, } \\
\text { from } 55955 \text { in } 2006 \text { to } \\
70462 \text { in } 2013 \text {. }\end{array}$ \\
\hline
\end{tabular}

The transformations over the past decades can also be evidenced by the changes in number of doctoral stu- dents (Table 5) and auditing and authorization of doctoral education (Table 6).

Table 5. Number of doctoral Students at Regular HEIs in China

\begin{tabular}{|c|c|c|c|}
\hline Year & Graduates & Entrants & Enrolment \\
\hline $\mathbf{1 9 9 8}$ & 7535 & 13041 & 39343 \\
\hline $\mathbf{1 9 9 9}$ & 8749 & 17724 & 47649 \\
\hline $\mathbf{2 0 0 0}$ & 9409 & 22292 & 59837 \\
\hline $\mathbf{2 0 0 1}$ & 11065 & 28663 & 76840 \\
\hline $\mathbf{2 0 0 2}$ & 12849 & 34003 & 43315 \\
\hline $\mathbf{2 0 0 3}$ & 16401 & 43315 & 122381 \\
\hline $\mathbf{2 0 0 4}$ & 20607 & 47502 & 148561 \\
\hline $\mathbf{2 0 0 5}$ & 24035 & 48824 & 172052 \\
\hline $\mathbf{2 0 0 6}$ & 31653 & 50078 & 188052 \\
\hline
\end{tabular}

\begin{tabular}{|c|c|c|c|}
\hline Year & Graduates & Entrants & Enrolment \\
\hline $\mathbf{2 0 0 7}$ & 36270 & 51916 & 201129 \\
\hline $\mathbf{2 0 0 8}$ & 38111 & 53595 & 214963 \\
\hline $\mathbf{2 0 0 9}$ & 42903 & 55472 & 224119 \\
\hline $\mathbf{2 0 1 0}$ & 43214 & 57392 & 236328 \\
\hline $\mathbf{2 0 1 1}$ & 44464 & 58882 & 248027 \\
\hline $\mathbf{2 0 1 2}$ & 48138 & 64118 & 268801 \\
\hline $\mathbf{2 0 1 3}$ & 49405 & 65785 & 281959 \\
\hline $\mathbf{2 0 1 4}$ & 52290 & 70713 & 305833 \\
\hline
\end{tabular}

Source: from statistics of MoE of China (1998-2014). 
Table 6. Auditing and authorization of doctoral education in China

\begin{tabular}{|l|c|c|c|c|c|c|c|c|c|c|c|}
\hline & $\begin{array}{c}\mathbf{1}^{\text {st }} \\
\text { audit } \\
\text { ing }\end{array}$ & $\begin{array}{c}\mathbf{2}^{\text {nd }} \\
\text { audit } \\
\text { ing }\end{array}$ & $\begin{array}{c}\mathbf{3}^{\text {rd }} \\
\text { audit } \\
\text { ing }\end{array}$ & $\begin{array}{c}\mathbf{4}^{\text {th }} \\
\text { audit } \\
\text { ing }\end{array}$ & $\begin{array}{c}\mathbf{5}^{\text {th }} \\
\text { audit } \\
\text { ing }\end{array}$ & $\begin{array}{c}\mathbf{6}^{\text {th }} \\
\text { audit } \\
\text { ing }\end{array}$ & $\begin{array}{c}7^{\text {th }} \\
\text { audit } \\
\text { ing }\end{array}$ & $\begin{array}{c}\mathbf{8}^{\text {th }} \\
\text { audit } \\
\text { ing }\end{array}$ & $\begin{array}{c}\mathbf{9}^{\text {th }} \\
\text { audit } \\
\text { ing }\end{array}$ & $\begin{array}{c}\mathbf{1 0}^{\text {th }} \\
\text { audit } \\
\text { ing }\end{array}$ & $\begin{array}{c}\mathbf{1}^{\text {th }} \\
\text { audit } \\
\text { ing }\end{array}$ \\
\hline $\begin{array}{l}\text { Year for auditing } \\
\text { \& authorization }\end{array}$ & 1981 & 1983 & 1986 & 1990 & 1993 & 1996 & 1998 & 2000 & 2003 & 2006 & 2011 \\
\hline $\begin{array}{l}\text { Number of } \\
\text { doctoral } \\
\text { programmes }\end{array}$ & 812 & 1151 & 1830 & 2107 & 2398 & 2604 & 1827 & 1397 & 2273 & 2878 & 1004 \\
\hline $\begin{array}{l}\text { Institutions } \\
\text { with doctoral } \\
\text { programmes }\end{array}$ & 151 & 196 & 238 & 248 & 271 & 277 & 323 & 312 & 342 & 361 & 288 \\
\hline
\end{tabular}

\section{Prospects in doctoral education in these two countries}

Given the glorious achievements both countries have made, they are confronted with huge challenges in many regards, such as optimizing recruiting strategy, diversifying of doctoral programs, bettering financing policies, and above all, intensifying quality control of doctoral education.

For instance, Andrzej Krasniewski (2008) analyzes the problems and challenges during the transformation of doctoral training in Poland, and demonstrates how these challenges have been dealt with in the Faculty of Electronics and Information Technology, Warsaw University of Technology, where a four-year doctoral programme, combining coursework and individual research work, was introduced.

After years of a dramatic increase in demand, Polish higher education enrollment will decline sharply by 2025. From 2006 to 2011, the total enrollment has decreased by 9.7 percent (GUS, 2011). This trend is consistent with findings presented by Levy (2012a) on the decline of private higher education globally (Joanna, 2014).

Despite some similar challenges, China has its particular tough tasks to handle. Within 4 decades, its scale of doctoral education has expanded to be one of the largest globally. In line with China's massive leap in higher education, doctoral education has been strongly, and arguably strategically pushed by the Chinese government (Yang, 2012). This is supported by Dr. Ma's study (2007) which reveals that the graduate education in China is closely related to the country's scientific policy and education reforms. "Chinese graduate education is still in its developing stage, and it faces many challenges" (p. 12). To summarize, the core issue of doctoral education is that the conflict between its size and quality has been deteriorating. Generally, while $\mathrm{PhD}$ student recruiting strategies and academic performance of universities are more efficient and effective, the financing imbalance and commercialization of doctoral education are increasingly pronounced. It is imperative to increase enrollment of graduate education and improve its quality, especially in students' capacity of conducting scientific research. To this end, the trends in two countries might occur in the following fields.

The scale of doctoral education in China will maintain steady or increase slightly while that in Poland will stabilize even downsize.

Due to demographic shrinking, Polish doctoral education will have slight increase and even shrink gradually while for China, its scale will maintain steady or an increase of reasonable proportion.

In Poland, the total population is $38,484,000$ ( as of the end of 31.12.2014), and the schooling population for higher education is declining, as the following table indicates. As a result, the scale of doctoral education is inevitably impacted, as the number of its doctoral graduates has accorded with the general trend of the total population, increasing from 4,400 in 2001 to 6,072 in 2007 , and then dropping sharply to 3,590 in 2012. Table 8 has demonstrated the volatility of student number in key years during the three stages. To maintain its size and international competiveness, Poland will enrich its source of potential students; in particular, giving more access to on-the-job students or international students. 
Table 7. Polish population by age group from 2000 to 2014

\begin{tabular}{|c|c|c|c|c|c|c|c|c|c|}
\hline & $\mathbf{2 0 0 0}$ & $\mathbf{2 0 0 5}$ & $\mathbf{2 0 0 8}$ & $\mathbf{2 0 0 9}$ & $\mathbf{2 0 1 0}$ & $\mathbf{2 0 1 1}$ & $\mathbf{2 0 1 2}$ & $\mathbf{2 0 1 3}$ & $\mathbf{2 0 1 4}$ \\
\hline $\mathbf{1 6}-\mathbf{1 0}$ & 2,044, & 1,707, & 1,585, & 1,519, & 1,453, & 1,386, & 1,326 & 1,268 & 1,222, \\
& 878 & 865 & 513 & 230 & 477 & 651 & 621 & 824 & 838 \\
\hline $\mathbf{1 9}-\mathbf{2 1}$ & 1,919, & 1,944, & 1,698, & 1,665, & 1,630, & 1,581, & 1,518 & 1,448 & 1,381, \\
& 542 & 457 & 015 & 521 & 551 & 467 & 562 & 754 & 483 \\
\hline
\end{tabular}

Source: from Education in the school year 2014-2015, GUS of Poland.

Table 8. Number of Polish doctoral students during 1980s-2010 s

\begin{tabular}{|l|l|l|}
\hline Stage & Academic year & Number of students \\
\hline Stage $\mathbf{1}$ & Before 1990 & No data \\
\hline Stage 2 & $1990-1991$ & 2,695 \\
\cline { 2 - 3 } & $1995-1996$ & 10,482 \\
\cline { 2 - 3 } & $2000-2001$ & 25,622 \\
\cline { 2 - 3 } & $2005-2006$ & 32,725 \\
\hline Stage 3 & $2007-2008$ & 33,040 \\
\cline { 2 - 3 } & $2014-2015$ & 40,575 \\
\hline
\end{tabular}

Considering that China is staying in the later phase of massification of higher education and knowledge economy is still maturing, there exists a lasting appetite for highly-educated labour force. Therefore, the huge size of its doctoral education is likely to continue but with a more reasonable increase rate.

However, one distinction between the two countries is meriting attention. Unlike Poland which allures on-the-job $\mathrm{PhD}$ applicants, there is an obvious trend in China to slash the scale of on-the-job doctoral students from early 2010s, especially at top research universities. For instance, 4 universities such as Zhejiang University and Xiamen University don't enroll on-the-job PhD students while universities like Xi'an Jiaotong University Renmin University of China has set limits on its proportion of such students, normally $15 \%$ of the total enrollment. Peking University and Beijing normal university have different requirements for such type of students, including designated regions, length of stay on campus and etc. (Shao \& Yu, 2015). The causes for the reduction of on-the-job doctoral students are twofold. Firstly, the completion rate of such students is low compared with regular $\mathrm{PhD}$ students. Secondly, it is to avoid corruption in the recruiting procedure.

The structure of doctoral education in the two countries will be diversifying and disciplines of STEM will be more highlighted.

In terms of structure of doctoral education, new types of doctoral programmes have appeared and disciplines of STEM will be more highlighted.
As "knowledge economy" has been the dominant feature in the $21^{\text {st }}$ century, the knowledge production and knowledge management have gradually shifted from Knowledge Mode 1 to Knowledge Mode 2, initiated by Gibbons et al (1994). In Mode 1, the way of producing knowledge is characterised by the Newtonian three phase ideal. Simplistically, basic science precedes applied science, which leads to technological development. And the knowledge producing institutions are universities, government research departments and laboratories, corporate laboratories, etc. In contrast, "Mode 2" involves a wider and different set of practitioners, concentrating on more specific and localised problems. Solving practical problems has been the main goal which requires the integration of different skills and knowledge - it is transdisciplinary.

Table 9. A summary of the distinctive attributes of each Knowledge Mode

\begin{tabular}{|l|l|l|}
\hline Attribute & Mode 1 & Mode 2 \\
\hline $\begin{array}{l}\text { Problems set/ } \\
\text { solved }\end{array}$ & $\begin{array}{l}\text { By academic } \\
\text { community }\end{array}$ & $\begin{array}{l}\text { In context of } \\
\text { application }\end{array}$ \\
\hline Motivation & $\begin{array}{l}\text { Increased } \\
\text { understanding }\end{array}$ & $\begin{array}{l}\text { Practical goal - } \\
\text { useful }\end{array}$ \\
\hline $\begin{array}{l}\text { Nature of } \\
\text { knowledge }\end{array}$ & Disciplinary & Trans-disciplinary \\
\hline $\begin{array}{l}\text { Quality } \\
\text { control }\end{array}$ & Homogeneity & Heterogeneity \\
\hline
\end{tabular}

Influenced by the changing modes, the structure of doctoral education worldwide has changed correspondingly, including both China and Poland.

Following the international trend, China has established a new type of doctoral programmes, specifically professional doctorate. Hitherto there have been five sorts of professional doctorate programmes (Doctor of Science in Engineering, Doctor of Medicine, Doctor of Veterinary Medicine, Doctor of Stomatological Medicine and Doctor of Education). In 2009, the China's 
State Council Academic Degrees Committee has approved 15 programmes of Doctor of Education. Currently Poland has regular $\mathrm{PhD}$ programmes and doctor in arts. In foreseeable future, more types of professional doctorate will be introduced, such as the establishment of Doctor by project in some western countries (Wang, 2012).
In terms of the structure of doctoral education, both countries will stress disciplines of STEM and devote more fund and resources for their development. As Table 10 demonstrates, doctoral students in the field of STEMs have increased steadily from 1995 to 2008, which corresponds with international trends during the time.

Table 10. Percentage of doctoral graduates in different disciplines from 1995-2008

\begin{tabular}{|c|c|c|c|c|c|c|c|c|c|c|c|c|}
\hline Discip & line & $\begin{array}{l}\frac{\lambda}{2} \\
\overline{0} \\
\frac{0}{0} \\
\frac{0}{2}\end{array}$ & 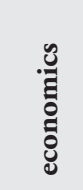 & 差 & 司 & 氖 & 总 & 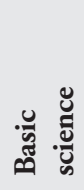 & & 苞 & 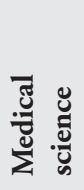 & 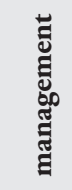 \\
\hline 1995 & $\begin{array}{l}\text { Number } \\
\text { percentage }\end{array}$ & $\begin{array}{l}57 \\
1.4\end{array}$ & $\begin{array}{l}184 \\
4.4\end{array}$ & $\begin{array}{l}98 \\
2.4\end{array}$ & $\begin{array}{l}52 \\
1.3\end{array}$ & $\begin{array}{l}103 \\
2.5\end{array}$ & $\begin{array}{l}74 \\
1.8\end{array}$ & $\begin{array}{l}1222 \\
29.4\end{array}$ & $\begin{array}{l}1565 \\
37.7\end{array}$ & $\begin{array}{l}141 \\
3.4\end{array}$ & $\begin{array}{l}655 \\
15.8\end{array}$ & $\begin{array}{l}0 \\
0\end{array}$ \\
\hline 1996 & $\begin{array}{l}\text { Number } \\
\text { percentage }\end{array}$ & $\begin{array}{l}78 \\
1.4\end{array}$ & $\begin{array}{c}221 \\
4\end{array}$ & $\begin{array}{l}140 \\
2.5\end{array}$ & $\begin{array}{l}42 \\
0.8\end{array}$ & $\begin{array}{l}133 \\
2.4\end{array}$ & $\begin{array}{l}116 \\
2.1\end{array}$ & $\begin{array}{l}1505 \\
27.3\end{array}$ & $\begin{array}{c}2151 \\
39\end{array}$ & $\begin{array}{c}227 \\
4.1\end{array}$ & $\begin{array}{l}898 \\
16.3\end{array}$ & $\begin{array}{l}0 \\
0\end{array}$ \\
\hline 1997 & $\begin{array}{l}\text { Number } \\
\text { percentage }\end{array}$ & $\begin{array}{l}93 \\
1.4\end{array}$ & $\begin{array}{c}302 \\
4.5\end{array}$ & $\begin{array}{c}202 \\
3\end{array}$ & $\begin{array}{c}65 \\
1\end{array}$ & $\begin{array}{l}191 \\
2.9\end{array}$ & $\begin{array}{l}144 \\
2.2\end{array}$ & $\begin{array}{l}1734 \\
26.1\end{array}$ & $\begin{array}{l}2572 \\
38.6\end{array}$ & $\begin{array}{c}273 \\
4.1\end{array}$ & $\begin{array}{l}1086 \\
16.3\end{array}$ & $\begin{array}{l}0 \\
0\end{array}$ \\
\hline 1998 & $\begin{array}{l}\text { Number } \\
\text { percentage }\end{array}$ & $\begin{array}{l}113 \\
1.3\end{array}$ & $\begin{array}{l}444 \\
5.3\end{array}$ & $\begin{array}{l}241 \\
2.9\end{array}$ & $\begin{array}{l}109 \\
1.3\end{array}$ & $\begin{array}{l}239 \\
2.8\end{array}$ & $\begin{array}{l}190 \\
2.3\end{array}$ & $\begin{array}{l}2218 \\
26.5\end{array}$ & $\begin{array}{c}3210 \\
38.3\end{array}$ & $\begin{array}{l}397 \\
4.7\end{array}$ & $\begin{array}{l}1222 \\
14.5\end{array}$ & $\begin{array}{l}0 \\
0\end{array}$ \\
\hline 1999 & $\begin{array}{l}\text { Number } \\
\text { percentage }\end{array}$ & $\begin{array}{l}148 \\
1.6\end{array}$ & $\begin{array}{l}507 \\
5.4\end{array}$ & $\begin{array}{c}284 \\
3\end{array}$ & $\begin{array}{l}145 \\
1.5\end{array}$ & $\begin{array}{l}343 \\
3.6\end{array}$ & $\begin{array}{l}198 \\
2.1\end{array}$ & $\begin{array}{l}2129 \\
22.6\end{array}$ & $\begin{array}{l}3723 \\
39.6\end{array}$ & $\begin{array}{l}351 \\
3.7\end{array}$ & $\begin{array}{l}1267 \\
13.4\end{array}$ & $\begin{array}{l}306 \\
3.3\end{array}$ \\
\hline 2000 & $\begin{array}{l}\text { Number } \\
\text { percentage }\end{array}$ & $\begin{array}{l}195 \\
1.7\end{array}$ & $\begin{array}{l}512 \\
4.6\end{array}$ & $\begin{array}{l}321 \\
2.9\end{array}$ & $\begin{array}{c}142 \\
1.3\end{array}$ & $\begin{array}{c}384 \\
3.4\end{array}$ & $\begin{array}{l}255 \\
2.3\end{array}$ & $\begin{array}{l}2280 \\
20.5\end{array}$ & $\begin{array}{l}4413 \\
39.8\end{array}$ & $\begin{array}{l}415 \\
3.7\end{array}$ & $\begin{array}{c}1775 \\
16\end{array}$ & $\begin{array}{l}397 \\
3.6\end{array}$ \\
\hline 2001 & $\begin{array}{l}\text { Number } \\
\text { percentage }\end{array}$ & $\begin{array}{l}214 \\
1.6\end{array}$ & $\begin{array}{l}608 \\
4.5\end{array}$ & $\begin{array}{l}441 \\
3.3\end{array}$ & $\begin{array}{l}185 \\
1.4\end{array}$ & $\begin{array}{l}486 \\
3.6\end{array}$ & $\begin{array}{c}267 \\
2\end{array}$ & $\begin{array}{l}3504 \\
26.2\end{array}$ & $\begin{array}{l}4602 \\
34.4\end{array}$ & $\begin{array}{l}517 \\
3.8\end{array}$ & $\begin{array}{c}2092 \\
15.7\end{array}$ & $\begin{array}{l}470 \\
3.5\end{array}$ \\
\hline 2002 & $\begin{array}{l}\text { Number } \\
\text { percentage }\end{array}$ & $\begin{array}{c}260 \\
1.8\end{array}$ & $\begin{array}{l}849 \\
5.9\end{array}$ & $\begin{array}{l}606 \\
4.2\end{array}$ & $\begin{array}{l}197 \\
1.4\end{array}$ & $\begin{array}{l}637 \\
4.4\end{array}$ & $\begin{array}{l}308 \\
2.1\end{array}$ & $\begin{array}{r}2772 \\
19.4\end{array}$ & $\begin{array}{l}4912 \\
34.4\end{array}$ & $\begin{array}{l}618 \\
4.3\end{array}$ & $\begin{array}{c}2392 \\
16.7\end{array}$ & $\begin{array}{c}738 \\
5.1\end{array}$ \\
\hline 2003 & $\begin{array}{l}\text { Number } \\
\text { percentage }\end{array}$ & $\begin{array}{c}322 \\
1.8\end{array}$ & $\begin{array}{c}1028 \\
5.6\end{array}$ & $\begin{array}{l}608 \\
3.7\end{array}$ & $\begin{array}{c}268 \\
1.5\end{array}$ & $\begin{array}{l}819 \\
4.5\end{array}$ & $\begin{array}{l}429 \\
2.4\end{array}$ & $\begin{array}{l}3529 \\
19.5\end{array}$ & $\begin{array}{c}6167 \\
34\end{array}$ & $\begin{array}{c}721 \\
4\end{array}$ & $\begin{array}{c}3099 \\
17.1\end{array}$ & $\begin{array}{c}1039 \\
5.7\end{array}$ \\
\hline 2004 & $\begin{array}{l}\text { Number } \\
\text { percentage }\end{array}$ & $\begin{array}{l}365 \\
1.6\end{array}$ & $\begin{array}{c}1254 \\
5.6\end{array}$ & $\begin{array}{l}913 \\
4.1\end{array}$ & $\begin{array}{c}344 \\
1.5\end{array}$ & $\begin{array}{l}987 \\
4.4\end{array}$ & $\begin{array}{l}465 \\
2.1\end{array}$ & $\begin{array}{l}4264 \\
19.1\end{array}$ & $\begin{array}{c}7781 \\
34.9\end{array}$ & $\begin{array}{l}867 \\
3.9\end{array}$ & $\begin{array}{r}3650 \\
16.4\end{array}$ & $\begin{array}{c}1375 \\
6.1\end{array}$ \\
\hline 2005 & $\begin{array}{l}\text { Number } \\
\text { percentage }\end{array}$ & $\begin{array}{r}436 \\
1.6\end{array}$ & $\begin{array}{c}1494 \\
5.4\end{array}$ & $\begin{array}{c}1118 \\
4\end{array}$ & $\begin{array}{l}416 \\
1.5\end{array}$ & $\begin{array}{c}1148 \\
4.1\end{array}$ & $\begin{array}{c}524 \\
1.9\end{array}$ & $\begin{array}{c}5331 \\
19.5\end{array}$ & $\begin{array}{c}9674 \\
35.2\end{array}$ & $\begin{array}{c}1083 \\
3.9\end{array}$ & $\begin{array}{l}4488 \\
16.3\end{array}$ & $\begin{array}{r}1727 \\
6.2\end{array}$ \\
\hline 2006 & $\begin{array}{l}\text { Number } \\
\text { percentage }\end{array}$ & $\begin{array}{l}515 \\
1.5\end{array}$ & $\begin{array}{c}2007 \\
6\end{array}$ & $\begin{array}{c}1610 \\
4.8\end{array}$ & $\begin{array}{c}530 \\
1.6\end{array}$ & $\begin{array}{c}1535 \\
4.6\end{array}$ & $\begin{array}{l}554 \\
1.7\end{array}$ & $\begin{array}{l}6754 \\
20.4\end{array}$ & $\begin{array}{c}10724 \\
32.2\end{array}$ & $\begin{array}{c}1331 \\
4\end{array}$ & $\begin{array}{l}5509 \\
16.5\end{array}$ & $\begin{array}{c}2162 \\
6.5\end{array}$ \\
\hline 2007 & $\begin{array}{l}\text { Number } \\
\text { percentage }\end{array}$ & $\begin{array}{l}549 \\
1.4\end{array}$ & $\begin{array}{c}2084 \\
5.4\end{array}$ & $\begin{array}{c}1826 \\
4.7\end{array}$ & $\begin{array}{c}720 \\
1.9\end{array}$ & $\begin{array}{c}1858 \\
4.8\end{array}$ & $\begin{array}{c}722 \\
1.9\end{array}$ & $\begin{array}{l}8348 \\
21.5\end{array}$ & $\begin{array}{c}14025 \\
36\end{array}$ & $\begin{array}{c}1776 \\
4.6\end{array}$ & $\begin{array}{c}3966 \\
10.2\end{array}$ & $\begin{array}{c}3013 \\
7.7\end{array}$ \\
\hline 2008 & $\begin{array}{l}\text { Number } \\
\text { percentage }\end{array}$ & $\begin{array}{l}557 \\
1.3\end{array}$ & $\begin{array}{c}2240 \\
5.4\end{array}$ & $\begin{array}{c}1934 \\
4.7\end{array}$ & $\begin{array}{c}719 \\
1.7\end{array}$ & $\begin{array}{c}1999 \\
4.8\end{array}$ & $\begin{array}{c}775 \\
1.9\end{array}$ & $\begin{array}{l}9499 \\
22.7\end{array}$ & $\begin{array}{c}14790 \\
35.7\end{array}$ & $\begin{array}{c}1833 \\
4.4\end{array}$ & $\begin{array}{c}3861 \\
9.3\end{array}$ & $\begin{array}{c}3232 \\
7.8\end{array}$ \\
\hline
\end{tabular}

Source: from General Development of Doctoral Education in China, 2011.

A similar scenario happens to Poland as well. The following table (Table 11), though not complete, demonstrates the percentage of Polish Doctoral Graduates in
Different Disciplines in 2009. Obviously, a vast majority of postgraduates are distributed in STEM disciplines.

Table 11. Percentage of Polish Doctoral Graduates in Different Disciplines in 2009

\begin{tabular}{|l|l|l|l|l|l|l|l|}
\hline country & $\begin{array}{l}\text { Natural } \\
\text { sciences }\end{array}$ & engineering & $\begin{array}{l}\text { Medical } \\
\text { sciences }\end{array}$ & $\begin{array}{l}\text { Agricultural } \\
\text { Sciences }\end{array}$ & $\begin{array}{l}\text { Social } \\
\text { sciences }\end{array}$ & humanities & others \\
\hline Poland & 26.6 & 20.1 & 11.0 & 7.7 & 17.8 & 16.8 & $\ldots$ \\
\hline
\end{tabular}

Source: OECD/UNESCO Institute for statistics/Eurostat Careers of doctorate Holders (CDH) project[DB/OL]. http://www.oecd. org/2015-01-19. 
Governance of doctoral education is decentralizing. In terms of the authority for institutions to deliver doctoral programmes, as Zhuang (2007) reveals that two groups of countries coexist. those in which the structure of higher education gives autonomy to institutions to offer a full portfolio of awards and those in which higher education is more closely controlled and managed by the state. The former group is typified by those countries that have followed a British model of higher education in which all institutions of higher education 1 are able to award doctorates. In Australia for example, as the population of universities has increased, those newly-designated have been granted research degree awarding powers.

At the other end of a continuum are countries in which the research degree awarding powers are to varying degrees far from automatic. Here universities themselves are not semi-autonomous organizations, including those in Japan, Poland and China. For example, universities have to apply for authorization to run programmes and make research degree awards - in these countries such authorization becomes a matter of controlled status and inevitably creates a stratified system.
Article 8 of Regulations on Academic Degrees in China stipulates that "the bachelor's degree shall be conferred by those institutions of higher learning authorized by the State Council. The master's and doctor's degrees shall be conferred by those institutions of higher learning and scientific research institutes authorized by the State Council. A list of institutions of higher learning and scientific research institutes that may confer academic degrees (hereinafter referred to as "degree-conferring entities") and the disciplines in which academic degrees may be conferred shall be submitted to the State Council by its Academic Degrees Committee for approval and promulgation.

Over the past decades, however, both China and Poland have loosened control over their doctoral education. For instance, on Nov. 25, 2015, China's State Council Academic Degrees Committee has stipulated that from 2016, HEIs are given more autonomy to manage their postgraduate programmes, particularly to adjust and optimize their master and doctoral programmes more timely and flexibly.

Table 12. Decentralization of degree-conferring autonomy in China

\begin{tabular}{|c|c|c|c|c|}
\hline & $\begin{array}{l}\text { Doctoral degree- } \\
\text {-conferring entities }\end{array}$ & $\begin{array}{l}\text { rights in selecting } \mathrm{PhD} \\
\text { supervisors }\end{array}$ & $\begin{array}{l}\text { Doctoral degree- } \\
\text {-conferring rights } \\
\text { in } 2^{\text {rd }} \text {-tier disciplines }\end{array}$ & $\begin{array}{l}\text { Doctoral degree- } \\
\text {-conferring rights } \\
\text { in } 1^{\text {st }} \text {-tier disciplines }\end{array}$ \\
\hline $\begin{array}{l}\text { China State Council's } \\
\text { Academic Degrees } \\
\text { Committee }\end{array}$ & $\begin{array}{l}\text { Offered the power for } \\
\text { auditing \& approving } \\
\text { since } 1981\end{array}$ & $\begin{array}{l}\text { Offered the power for } \\
\text { auditing \& approving } \\
\text { since } 1981\end{array}$ & $\begin{array}{l}\text { Offered the power for } \\
\text { auditing \& approving } \\
\text { since } 1981\end{array}$ & $\begin{array}{l}\text { Offered the power for } \\
\text { auditing \& approving } \\
\text { since } 1996\end{array}$ \\
\hline $\begin{array}{l}\text { Academic Degrees } \\
\text { Committee at } \\
\text { provincial level }\end{array}$ & $\begin{array}{l}\text { Offered the } \\
\text { power for recommendat } \\
\text { ion since } 2005\end{array}$ & --- & --- & $\begin{array}{l}\text { Offered the power for } \\
1^{\text {st }} \text { round auditing since } \\
2010\end{array}$ \\
\hline $\begin{array}{l}\text { Degree-conferring } \\
\text { HEIs }\end{array}$ & -.- & $\begin{array}{l}\text { Offered the power for } \\
\text { self-auditing experiment } \\
\text { since } 1985\end{array}$ & -.- & $\begin{array}{l}\text { Offered the power for } \\
\text { self-auditing Since } 2005\end{array}$ \\
\hline $\begin{array}{l}\text { State of degree- } \\
\text {-conferring }\end{array}$ & $\begin{array}{l}\text { No loosening, } \\
\text { State-Controlled }\end{array}$ & $\begin{array}{l}\text { Decentralized to degree- } \\
\text {-conferring entities }\end{array}$ & $\begin{array}{l}\text { Decentralized to degree- } \\
\text {-conferring entities }\end{array}$ & $\begin{array}{l}\text { Decentralized to degree- } \\
\text {-conferring entities }\end{array}$ \\
\hline
\end{tabular}

In the interview with Chinese Global Times on Oct. 5, 2015, the Deputy-Minister of Science and Higher Education, Ms. Daria Lipinska Nalecz comments that the year 2011 is a turning point in reformation of higher education, when Polish HEIs have been offered more autonomy (Global Times, 2015). Since 2011 the Ministry of science and higher education will not decide the teaching standard and requirement for each discipline. The HEIs are able to design their teaching plans, adjust the structure of their disciplines in accordance with the market.

\section{Quality of doctoral education will be more stressed and its control will be intensified.}

The maintenance of high quality of doctoral education has been the top priority

for both countries. Poland has internal and external quality assurance system in its higher education. As Chmielecka (2009) point out, there are two principal accreditation schemes in Poland. SAC which was established in 2002 (The State Accreditation Committee, or Panstwowa Komisja Akredytacyjna - PKA) is 
the national scheme (state-owned) while CRASP (the Conference of Rectors of Academic committee) is typical of the academic schemes, specifically the CRASP Accreditation Committee which was formed in 2001.

Though academic accreditation schemes are gaining more weight in monitoring the quality of Polish doctoral education, or quite a long period, national accreditation scheme will still be the predominant force. As a powerful national accreditation scheme, the PKA applies a uniform mechanism of education quality assessment to all higher education institutions/fields of study and to monitor compliance with the requirements for institutions offering higher education. The requirements are centrally-adopted standards equally applicable to all fields of study. Therefore, PKA is a typical accreditation serving to confirm the accountability of a higher education institution/faculty offering higher education degree programmes. Chmielecka (2009) comments, "This accreditation has consequences of administrative nature and may lead to the elimination of a programme or closing down of a higher education institution" (p. 152). In recent years, in conformance with requirements of the European Research Area, Poland has been involved in a series of conferences on doctoral education, many of which has emphised the urgency of quality in the field. For instance, on 17-18 June 2010, there was a Bologna Seminar on Doctoral Studies in the European Higher Education Area in Warsaw.

Likewise, China has also taken stringent measures to maintain the quality of its doctoral programmes. Basically, it has gradually shifted from the "Entry-centered quality control mechanism", which exerts strict control in selecting $\mathrm{PhD}$ students and authorization of doctoral programmes, to "Process-centered quality control mechanism" (Guo, 2009), which oversees the quality of doctoral education from the beginning to the end. What's more, the task for overseeing doctoral education will not be government-dominated, but government-led and accreditation agency-implemented.

In 2011, The Academic Degrees Committee of the State Council amended the 1997 Classification of Instructional Programs. In 2013, The Academic Degrees Committee of the State Council and the Ministry of Education jointly issues Basic Requirements of Doctors and Masters in First-tier Disciplines. To scrutinize the quality of doctoral education, China will implement large-scale examination in Doctor Degree Conferring Institutions every $4-5$ years. Those HEIs which fail to pass the examination will have serious consequences, either being asked to improve their programmes within given time (normally 2 years), or having their authori- zation of doctoral prorgrammes revoked completely. For instance, on $25^{\text {th }}$ of March, 2016, the China's State Council Academic Degrees Committee has revoked 4 Doctor Degree authorizations at four research universities, i.e., those four universities lost their qualification for enrolling PhD students in the disciplines.

To avoid the weakness of selecting students mainly via examination, some Chinese universities including Peking University and Xiamen University have tried "Application-Audit" mechanism in $\mathrm{PhD}$ enrollment from 2014. And new mechanisms in assessment and elimination of postgraduates have also been introduced and implemented. If doctoral students fail to pass midterm assessment, they will be refused to continue their candidateship.

\section{Internationalization of doctoral education will deepen in both countries.}

Internationalization of doctoral education has been trendy over the past decade. Internationalization of doctoral education involves myriad facets, such as internationalization of students, teachers, teaching content and even teaching materials. Above all, it signifies the internationalization of students.

In a sense, Poland stands in a better position than China mainly due to two major reasons. Firstly, it has been a constant goal for EU to promote integration in many aspects (especially in education and economy) among its member countries, as evidenced by the establishment of European Research Area and European Higher Education Area. Specifically, "Socrates/ Erasmus Programmes" are the two most well-known schemes to promote the mobility and exchange of doctoral students. Secondly, to minimize the negative effect of its downsizing schooling population and maintain its edge in higher education, Poland is taking two major measures, to giving more access to adult students to its doctoral programmes, in particular, on-the-job students, and to attract more international students.

For many years China has been one of the major exporters of highly-skilled talents into other countries, thus witnessing a severe "brain drain". In this sense, it is seeing a deficit of Internationalization of doctoral education. Encouragingly, the tide is turning slowly. Statistics also show foreign graduate students in Chinese universities are on the increase (as was shown in Table 13), though most of them are in language programs and humanities, and come mainly from neighboring countries or African countries. 
Table 13. Number of international students for PhD degree from 2009-2013 in China

\begin{tabular}{|c|c|c|c|c|}
\hline Academic year & $\begin{array}{c}\text { Total number of full- } \\
\text {-time international } \\
\text { students }\end{array}$ & $\begin{array}{c}\text { Number of Doctoral } \\
\text { candidates }\end{array}$ & $\begin{array}{c}\text { Percentage of PhD } \\
\text { students against total } \\
\text { number }\end{array}$ & $\begin{array}{c}\text { Year-on-year Rate of } \\
\text { increase of PhD students }\end{array}$ \\
\hline $\mathbf{2 0 1 3}$ & 14.7890 & 9.774 & 6.6 & $17.72 \%$ \\
\hline $\mathbf{2 0 1 2}$ & 133.509 & 8.303 & 6.2 & $19.93 \%$ \\
\hline $\mathbf{2 0 1 1}$ & 118.837 & 6.823 & 5.7 & $18.83 \%$ \\
\hline $\mathbf{2 0 1 0}$ & 107.432 & 5.826 & 5.4 & $22.62 \%$ \\
\hline $\mathbf{2 0 0 9}$ & 93.450 & 4.751 & 5.1 & $21.57 \%$ \\
\hline
\end{tabular}

Source: from Annual report on China's Graduate Education Quality 2014 by Research Center for Graduate Education of Beijing University of Technology, 2015.

\section{Conclusion}

This paper, based on policy analysis and abundant data, has compared the transformations and trends of doctoral education in China and Poland from 1980s to 2010s. Findings show that the political transitions in late 1980s, its integration with European education system in early 2000s, and particularly joining the Bologna Process are the driving force for its transformation in the sector, while the national economic policy and the government behavior provoke the changes for China.

In the next few years, probably China's doctoral education will remain at the current level or even expand modestly, while that of Poland is likely to shrink due to the population decline. What's more, Poland and China are expected to further diversify their structure in doctoral education. As a result, professional doctorate will grow quickly. Besides, they will pay closer attention to STEM discipline in response to changing modes of knowledge production. To improve the quality, both countries will introduce more intermediary accreditation agency, slackening the once-tightened management mechanism, and promote the level of internationalization.

In this paper, China refers to the mainland China, so the data about Hong Kong, Taiwan and Macao are not included.

\section{References}

Cai X.J., Fan W. (2011). General development of doctoral education in China. Beijing.

Chen H.J, et al. (2010). Quality of PhD: conception, evaluation and trend. Beijing.

Che S.F. (2005). EFL teaching at Polish higher education institutions and its implication for China. Teaching and Education, (11), 60-62.

Chen X. (1998). The engineering education reform in Poland. Research on Education Tsinghua University, (2), 132-135, 147.
Chmielecka E. (2009). National external quality assurance system in Poland and implementation of the European standards and guidelines. In Kohoutek J. (ed). Implementation of standards and guidelines for quality assurance in higher education of Central and East-European countries - Agenda ahead. Bucharest.

Fan Y. (2001). Comparison and reference between Poland China in higher education. Research on education Tsinghua University, (3), 131-135.

Gibbons M. et al. (1994). The New Production of Knowledge. London: SAGE.

Global Times. It is envious to observe the fierce competition among top universities in China - an interview with Deputy-Minister of Science and Higher Education. [2015-10-05]. http://news.sina. com.cn/o/2015-10-09/doc-ifxiqtqy0581635.s html.

Guo J.R. (2009). Expansion of doctoral education, quality distribution and quality assurance of doctorate in Chinese Universities. A perspective of the institutionalism. Peking Education Review, (4), 21-47.

Holm T., Sammalisto, K., Vuorisalo, T. (2015). Education for sustainable development and quality assurance in universities in China and the Nordic countries: a comparative study. Journal of Cleaner Production, (107), 529-537.

Huang C.X. (2001). The current state and reforms of Polish agricultural education. Higher Agricultural Education, (8), 93-95.

Huang C.Z. (2002). The mode of polish higher education and references to China. Hubei Social Sciences, (10), 54-55.

Huang X.B., Ke Z.Y. (2011). The entrepreneurship education of Polish higher education institutions and references to China. Higher Education Exploration, (4), 66-69.

Kraśniewski A. (2008). Transformation of doctoral training in Poland. Higher Education in Europe, 33(1), 125-138.

Kwiek M. (2013). From System Expansion to System Contraction: Access to Higher Education in Poland. Comparative Education Review, 7(3), 553-576.

Kościelniak C. (2014). A consideration of the changing focus on the sustainable development in higher education in Poland. Journal of Cleaner Production, 62(11), 114-119.

Lee A., Green B. (1995). Introduction: Postgraduate Studies/Postgraduate Pedagogy?. Australian Universities' Review, 38(2), 2-4.

Ministry of Science and Higher Education. 2012. http://www.nauka. gov.pl/en/higher-education/

MOE of People's Republic of China. [2015-05-21] http://moe.gov.cn/ srcsite/A03/moe_634/201505/t20150521_189479.htm l.

Musial J. (2014). Polish higher education - intersectoral distinctiveness. European Education, 46(3), 55-74.

OECD. Education and Training, Share of foreign-born among doctoral and tertiary-level graduates in OECD countries. [DB/OL]. [2015-01-22]. http://stats.oecd.org/. 
OECD/UNESCO Institute for statistics/Eurostat Careers of doctorate Holders (CDH) project [DB/OL]. http://www.oecd.org/201501-1.

Pang L. (2006). The review on accreditation system of quality control in Polish higher education, (3), 146-149.

Piotr W.J., Marek K. (2007). Doctoral education in Poland. In: Stuart P., Howard G., (eds). The Doctorate Worldwide. Berkshire.

Research Center for Graduate Education of Beijing University of Technology. (2015). Annual report on China's graduate education quality 2014. Beijing.

Shao K.Q., Yu W.H. (2013). Problems in and suggestions for current enrolment system for doctoral students. Journal of graduate education, (5), 58-62.

Sun X.B., Xia J. (2003). The non-public higher education institutions in Poland. Comparative education review, (6), 82-85.

Wang D.F. (2012). The evaluation of quality of doctoral education: Challenges and implications. Degree and Postgraduate Education, (2), 14-19.
Wildy H., Peden S., Chan, K. (2015). The rise of professional doctorates: case studies of the Doctorate in Education in China, Iceland and Australia. Studies in Higher Education, 40(5), 761-774.

Yang X.F. (2015). New trends and implication of transformational development of Polish higher education. Comparative education review, (9), 61-66.

\section{Biodata:}

Yong MEI has been an EFL teacher at Hubei University in Wuhan, P.R.C. of China. He is also PhD candidate in Higher Education Management at Huazhong University of Science and Technology in Wuhan. His research interest is higher education management and teacher development.

Email: Forrest. Yong. Mei@outlook.com 